\title{
Subjectification Strategy of Author's Statement in English Literary Xeno-Narrative
}

\author{
Liudmila V. Kulikova* \\ and Elizaveta Iu. Mikalauskaite \\ Siberian Federal University \\ 79 Svobodny, Krasnoyarsk, 660041, Russia
}

Received 08.07.2019, received in revised form 26.08.2019, accepted 06.09.2019

Literary xeno-narrative is a text illustrating the experience of interaction with cultural otherness that focuses on contrasting the in-group/out-group categories, with adaptation stress minimization and mental experience transfer as xeno-narrative functions. The author of the xeno-narrative forms the idea of the perfect reader through the implementation of strategies aimed at the recipient. The subjectification strategy of the author's statement in literary communication is aimed at the reader's personal acceptance of the author's meanings in the text and the reader's emotional involvement and empathy. This process is represented through the lexical and emotionally connotative language tools in xeno-narrative texts and also readers' reviews corpus. The results of the study indicate the difference in the process of subjectification, understanding of content and the author's emotional intentions among the readers with different national worldviews. The study is based on the materials of the electronic corpus of English and Russian readers' reviews of the analysed narrative text. English-speaking readers recorded thematic units typical for the xeno-narrative and showed a high level of empathy to the immigrants' experience associated with the personal experience of overcoming otherness. Russian-speaking readers drew on the thematic unit associated with intercultural interaction to a lesser extent, focusing on the timeline of growing up.

Keywords: narratology, xeno-narrative, literary narrative subjectification strategy, intercultural communication.

The study is based on the material of the electronic corpus of English and Russian-language readers' reviews on the analyzed narrative texts.

Research area: linguistics.

Citation: Kulikova, L.V., Mikalauskaite, E. Iu. (2019). Subjectification strategy of author's statement in English literary xeno-narrative. J. Sib. Fed. Univ. Humanit. soc. sci., 12(9), 1648-1658. DOI: 10.17516/1997-1370-0479.

(C) Siberian Federal University. All rights reserved

* Corresponding author E-mail address: info_ifiyak@sfu-kras.ru ORCID: 0000-0002-1622-8304 (Kulikova)

This work is licensed under a Creative Commons Attribution-NonCommercial 4.0 International License (CC BY-NC 4.0). 


\section{Introduction}

Literary communication is a special kind of indirect communication between the speech generation subject and its recipients. One of the main distinctions of literary communication is lack of the participants' involvement in a pragmatic situation: only a written text stands as an intermediary between them.

Literary narrative includes several levels of communication, or narrative levels. At the in-text level it is communication between characters, at the external text level it is between an abstract author and an ideal reader. The complexity of the narrative communicative structure is complemented by the presence of a real author who is a living person, a person with a unique experience, values and opinions. Therefore, the dualistic system of communication in the study of literary narrative should be expanded to a triangle: the real author - the abstract author (narrator) - the reader.

The object of this study is a particular type of the narrative text called xenonarrative herein. It is defined as a narrative immersed in the discourse of intercultural interaction illustrating the experience of interaction with cultural otherness, focusing on the in-group/out-group category. Themes in the xeno-narrative are limited by numerous negative descriptions of the background of staying in a foreign country, mastering a new language and communicating with representatives of other cultures.

The communicative structure of the xeno-narrative is often first-person, as the real author of this text type should have his/her life experience related to the experience of cultural otherness, and minimisation of stress adaptation and transfer of mental experience constitute the xeno-narrative functions. The real author and his/her experiences are prototypes for the abstract author's image and the plot of the xenonarrative. The creator of the xeno-narrative, as well as of any other literary text, builds a representation of an ideal reader's image, closing the communicative triad. The ideal recipient of the xeno-narrative, according to the author, also must possess a number of conceptual attitudes and values for interpretation of the communicative purpose closest to the author. The idea of the ideal reader is represented in the form of the author's strategies when creating a text.

\section{Theoretical Basis}

A lot of fundamental works are devoted to the study of the author's strategies in the process of literary communication (Dijk, Kintsch, 1988; Eco, 2002) and narrowlyspecialised studies investigating more specific strategies in the text (Ziuzina, Suvorova, 2016; Manzheleevskaya, 2016; Mel'nichuk, Androsova, Elivanova, 2013, etc.). The 
researches devoted to the study of the author's subjectification strategy is of particular interest in this paper, that is, the reader's personal acceptance of the author's statement.

In his work on the process of subjectification A.S. Komarov suggests that in the text the author implements the strategy to ensure the reader's most effective perception of the text. Subjectification does not mean acceptance of the author's position; on the contrary, the reader can resist the opinion of the narrator or the hero. The author also tries to transfer the reader to the emotional space identical to the text statement. The process of subjectification of the author's statements is opposed to objectification as "removal of the author's statement from the self and its depersonalisation by the reader" (Komarov, 2014: 253).

Methodological and terminological basis of A. S. Komarov's research is built upon J. Bugental's theory of existential psychology with the author naming the process of paralleling the key to the success of internal conversation. That is, building parallels thematic, emotional, and psychological — leads to the fullest possible perception of the interlocutor's intentions (see Bratchenko, 2001).

Describing a similar author's strategy, E. G. Kornyshkova uses a different methodological approach. She analyses "the strategy of enhancing the perception of the text of the English author's fairy tale" and examines linguostylistic means (e. g. the techniques of hyperbole and parenthesis, language play with the semantic content of a word or an idiom) of the text as "elements of the author's strategy to provide the most complete semantic perception of the text of the work" (Kornyshkova, 2012: 78).

The authors of these studies indicate that the author's strategy to enhance the perception of the text is implemented by the linguistic means of different levels: phonetic, grammatical, and stylistic. A.S. Komarov includes such characteristics as themes, feelings, emotions and experiences, the breadth and depth of the topic or problem coverage, the inner world of man, and the relationship between people in the content of the author's statement. The researcher names the key to the subjectification strategy successful implementation, the key being "the reader's willingness to expand, deepen his/her views on a particular issue. And the signs of success can be a return to conversation with the author, a return to the already read, a return to the topic or experience, as well as links to repetition, often not very conscious, places, words, situations from the author's statement" (Komarov, 2014: 258). E. G. Kornyshkova expands these conditions with "understanding the system of content images of the text in their mutual connection" (Kornyshkova, 2012: 80). She argues: "Therefore, the degree of completeness of the perception of the target audience of a text varies 
depending on the readers' background knowledge, goals and motivation of their encounter with the text" (Kornyshkova, 2012: 80).

Thus, the subjectification strategy of the author's statement is manifested through the use of a variety of linguistic and discursive means in the text. The factors of the strategy successful implementation, that is of the reader's maximum perception of the author's intentions, are their background knowledge, their cultural background, and their readiness to perceive the text. The subjectification strategy success or failure in a particular text can be measured by comparing the results of the linguistic analysis of a fictional text and the readers' feedback on it. It is possible to study the subjectification strategy of xeno-narrative texts through the analysis of the readers' reviews.

\section{Subjectification strategy in xeno-narrative}

The current study identifies the subjectification strategy of xeno-narrative texts through the analysis of the readers' reviews. One example of the xeno-narrative text is Jean Kwok's novel Girl in Translation. Written in English in 2010, it was aimed primarily at the American audience. Since its publication on the www.goodreads.com website of the readers' reviews, the reviews of the book have kept coming in. At the moment, the readers' reviews corpus includes 4958 texts. The readers write reviews in English. However, many of them do not live in the US but also, to name a few, in Japan, Canada or Australia. In 2011, the novel was translated into Russian and the www.livelib.ru website saw 423 reviews from Russian-speaking readers. The readers' reviews corpus in this study is made up of 50 reviews by Russian-speaking readers and 50 ones by English-speaking readers. The English-language corpus contains the readers' feedback from different countries: the USA, Canada, Japan, Australia, etc. The greatest attention in the analysis was paid to the texts of the recipients who indicated the USA as their place of residence, as well as to the reviews by Asian readers. This is due to the plot of the xeno-narrative under the research: Chinese immigrants' life in the United States. In the course of analysing the readers' corpora it was possible to determine the level of correspondence between the author's encoding of the aesthetic concept by linguistic and discursive means and an adequate decoding of the statement by the readers.

In the course of discursive processing of the negative experience in the text, certain thematic units are used, a system of emotive statements is formed, and the actions of the characters experiencing otherness are described as representing certain cultural and psychological conditions of their behaviour in the process of adaptation. 
In Girl in Translation the following thematic units, characteristic of the xenonarrative text, are most fully presented: moving to a new country, difficult adaptation to the American school, communication problems in dealing with the Americans, the language barrier, and difficult social conditions such as poverty and illegal employment. The novel belongs to the literary genre of young-adult fiction, that is, to teenage literature. Therefore, the text also revises the topics specific to this genre: the process of growing up, first love, and difficulties in socialising with the peers.

The first condition for successful implementation of the subjectification strategy of the reader's perception is the understanding of the system of content images in the text. In the English-speaking readers' corpus most of the reviews reflect on the topics typical of the xeno-narrative: "immigrant experience"; "Chinese mentality"; "the struggle of a Chinese girl growing up in the US"; "she struggles of being pushed into a foreign world, where people look different, have other traditions, other norms, and speak an entirely different language". To display the features of immigration experience in the xeno-narrative, the readers use the lexemes with the meaning "hard, with difficulty": struggle, strive, hardship, survival. The reception of the xeno-narrative text by the English-speaking audience reflects the implementation of the subjectification strategy of the author's statements associated mainly with cross-cultural themes of the novel.

The sub-corpus of the English corpus, including the responses of the USA readers, highlights a recurring thematic unit which is atypical for both Asian and Russian corpora. This unit is connected with the national American idea of the American dream. This global concept is connected to the life ideals of the Americans - freedom of speech and fulfilment, achievement of dreams. The concept of the American dream embraces the idea of the immigrants' journey in the United States in the status of the people who fled from difficult social and living conditions in their own country. The idea of the American dream also contains the idea of a self-made person, a person who managed to achieve the desired goal through hard work.

American readers define the fulfilment of the American dream as one of the main themes of the Girl in Translation xeno-narrative:

"Can this girl that barely speaks any English and curls up with blankets from a dumpster while stomping on the floor to scare off roaches achieve the American dream?";

"Kimberly, the young girl, is exceptionally bright so is able to get into a private school on a scholarship and is able to fulfill the American dream of working hard and becoming a success". 
The readers interpret the plot of this literary xeno-narrative as the story of the American dream fulfilment: anyone, especially an immigrant, is able to achieve success if they work. Kimberly, the main character, is aimed at achieving such a model of social growth: learn the language, earn a degree and a well-paid job, and become an American citizen. However, among the 50 reviews in the English corpus, there appears an opinion sharply opposing the interpretation of the idea of the American dream in the xeno-narrative: "I loved that Kwok wasn't holding her punches when it came to ruining the image of "the American dream". For some reason, it's an image that is embedded into the minds of all of those who migrate to United States. Better future, better jobs, better housing etc. When it comes to this story - it was nothing like that".

This xeno-narrative also puts the emphasis on the themes of the American dream destruction. The narrator describes the fate of minor immigrant characters working in a factory or living in Chinatown. Mr. Pak, who got under an ironing press, is not allowed to call for medical assistance, factory workers are not able to find another job, earn more and break out of the illegal labour system:

"Once she was gone, Ma whirled on me.

- Don't interfere when adults are talking! Who will fill our mouths with food when we don't have any work?

- It is a free country, Ma. Why do we have to work for her?

- Free country! Who do you think owns the other clothing factories? They're all family or friends with each other. The whole Chinatown garment industry (Kwok, 2010: 188).

Most immigrants are hard-working but do not have the opportunity to get a good education, learn the language or get a high-paying job. Thus, the theme of the American dream fulfilment finds its double interpretation in the novel: on the one hand, the main character Kimberly embodies this idea, having achieved success in a foreign country, on the other hand, the examples of other characters from Chinatown indicate a frequent inability to transcend the borders of Chinatown due to their illegal status.

A different semantic group is widespread in Russian readers' reviews. It is determination. In 43 out of 50 reviews there are lexemes with the semantics of struggle, aspiration, perseverance: "Such a childhood cannot be called a normal life, continuous survival and strive"; "And Kim's magical abilities are her brains and determination"; "Kimberly Chang is a very persistent girl who knows what she wants and will achieve what she wants". Similar to the English corpus, the verbs with the seme "hard, with difficulty" are frequent: the heroine sacrifices, survives, drags her family, succeeds etc. The readers evaluate Kimberly positively: she is a hard worker, a clever girl, a thinking 
girl, her character is described by the nouns with the semantic meaning of "hard, with difficulty": endurance, determination, diligence, perseverance. $90 \%$ of the Russian reviews are devoted to the heroine's difficult journey, her determination. This indicates a profound process of the Russian readers' subjectification, as the novel demonstrates such thematic parallels as that when the heroine often uses similar lexemes describing the purpose of her adaptation:

"It was the closest Ma would ever come to expressing regret at her choice to come to America. I understood what my task was now and I laid my cheek against her shoulder. "I'm going to get us both out of here, Ma, I promise" (Kwok, 2010: 56). She describes communication at school using the words of the semantic group "war":

"Mr. Bogart took off some credit for this, so I didn't get a hundred on that test, but I'd seen enough to know that a few minor adjustments were all I required for the next time. This was a fight where I actually had a chance" (Kwok, 2010: 59).

Reception of the author's position by the Russian readers is connected to the theme of struggle and survival and practically does not correlate with the theme of intercultural difficulties in the process of adaptation.

In the reviews of multilingual corpora, descriptions of other thematic units employed in the novel Girl in Translation are frequent: the love line of the main character and the story of her growing up. These two themes are characteristic of the young adult fiction genre but are not associated with the cross-cultural context important to the present analysis of literary xeno-narrative. The readers' grasp of these thematic units directly affects the differentiated assessment of this literary work on the reviews site. The novel Girl in Translation on Goodreads is rated 3.97 out of possible 5.0; on the Russian site LiveLib the rate of the novel is 4.3. All the readers' reviews with the ratings of 1 or 2 points refer to the love line of the narrative, which, according to the authors of the reviews, does not deserve high praise:

"Seriously, I was so annoyed at the last $1 / 8$ th of this book"; I could not get past was the very end - where Kim doesn't tell Matt that she actually had their kid. <...> Yes, I did get pissed at the ending.

Many Russian readers also point to the novel's artistic shortcomings:

"But the storyline is told rigidly, there's a feeling that the author wanted to say about everything at once, and certainly very briefly. And the character of Kimberly remains murky;

"The arrangement of the characters is so banal, I want to cry. It all starts well, but then the reader dives into a children's fairy tale, and stereotypical at that"; 
"By the middle of the book the reader's involvement in the story and the atmosphere are gradually fading."

The next important condition of the readers' attitude subjectification is emotional involvement. This means that the text evokes the reader's emotional response: "If the reader attaches the same importance to the feelings that the author attaches to them, then we can talk about finding two subjects in the same emotional space" (Komarov, 2014: 255).

In the texts of the readers' reviews emotional involvement is introduced through the use of emotive constructions with both positive and negative connotation. Both in English and Russian reviews negative emotive words are frequent to describe the heroine's living and social conditions: horrid conditions, slave exploitation, cruel life, horrible place etc. Or poverty, terrifying slums, earn pittance. The recipients use metaphors and intertextual images: the hell of everyday life, a purely Dickensian factory. This emotive vocabulary is completely parallel to the emotive words in the text where the heroine describes new realities: "vile”, "impossible”, "poor".

However, there is a deep gulf between the two readers' worldviews in the process of the reception while analysing the emotive vocabulary directly related to the readers' feelings. The Russian-speaking readers experience empathy for the difficulties of the heroine's adaptation but are not able to accept, to sink into the emotional space: "It's hard to imagine myself such an immigrant".

They perceive the text of the xeno-narrative as a story about a new, unfamiliar experience:

"To read it to better understand other people and their troubles. To understand without translation"; "to breathe a sigh of relief because all these horrors and ordeals do not happen to you and your nearest and dearest".

The American readers, on the contrary, broadcast their own experience of overcoming cultural otherness. Some of them survived the stress of acculturation:

"It's like Ms. Kwok took pieces of my own experience and lines lifted from my friends' stories"; "I am very much an ABC, American-born-Chinese". Others are involved in this experience through their parents: 'I'm not a stranger when it comes to immigrant experiences - my mother and father were both immigrants". A similar experience activates the appearance of evaluative structures with the seme "correct, true": "while my experience was thankfully nothing like hers, some things sang true anyway"; "It is fiction but it could have been real".

Such judgments are also found in the Russian reviews: the story is "sincere, not farfetched, correct", "I believed every word." Such assessments seem to be associated with 
the author Jean Kwok's direct experience of overcoming cultural otherness. The author's real experiences transfer the readers into the space of emotional trust: "the author knows firsthand what she writes about"; "the author translates the slang and the phrases, the cultural traditions, the deeply embedded lifestyle that is Chinese pride and saving face".

\section{Conclusion}

The subjectification strategy of the author; s statements in the xeno-narrative is aimed at the most complete view of the system of the author's themes and images, as well as the reader's emotional engagement and empathy. The English-speaking audience, toward which the novel Girl in Translation was primarily oriented, recorded thematic units typical for the xeno-narrative related to the problems of adaptation and intercultural communication. They also established coherent connections between the described fictional experience and their own one. The credibility of the author's narrative forms a parallel xeno-narrative to the emotive text units: negative assessment of the difficulties of adaptation, positive assessment of the heroine's personality. The Russian-speaking readers grasped the thematic unit associated with overcoming cultural otherness to a lesser extent, focused on the storyline of growing up and the heroine's determined character. It is possible to link the difference of the readers' receptive vectors to different cultures with the experience of their interaction with other cultures. Many Americans are first or second-generation immigrants. Thus, cultural diversity in their country allows them to form a full picture of the experience of overcoming cultural otherness in their new compatriots through the reception of discursive processing means in the xeno-narrative.

\section{References}

Bratchenko, S.L. (2001). Ekzistentsial'naia psikhologiia glubinnogo obshcheniiauroki Dzheimsa Biudzhentala [Existential Psychology of Internal Conversation. James Bugental's Lessons]. Moscow, Smysl, 91 p.

Dijk, T., Kintsch, W. (1978). Toward a Model of Text Comprehension and Production. In Psychological Review, 5 (85), 363-394.

Eco, U. (1994). Six Walks in the Fictional Woods. Harvard University Press, 153 p.

Komarov, A.S. (2014). Avtorskaia strategiia v protsesse khudozhestvennogo obshcheniia s chitatelem [Author's Strategy in the Process of Artistic Communication with Readers]. In Vestnik MGIMO universiteta [MGIMO Review of International Relations], 3, 252-260. 
Kornyshkova, E.G. (2012). Lingvisticheskie strategii usileniia vospriiatiia teksta angloiazychnoi avtorskoi skazki [Linguistic Strategies for Enhancing the Perception of the Text of the English Author's Fairy Tale]. In Perspektivy nauki [Science Prospects], $11,76-81$.

Kwok, J. (2010). Girl in Translation. N.-Y, Riverhead Books, 320 p.

Manzheleevskaya, E.V. (2016). Pragmalingvisticheskaia strategiia stimulirovaniia avtorom chitatel'skoi zainteresovannosti i ee rechevye signaly (na materiale russkoiazychnykh i angloiazychnykh khudozhestvennykh tekstov) [Author's Pragmalinguistic Strategy to Stimulate Readers' Interest and its Speech Signals (by the Material of Russian and English Literary Texts)]. In Filologicheskie nauki. Voprosy teorii $i$ praktiki [Philological Sciences. Issues of Theory and Practice], 12 (66), 2, $133-138$.

Mel'nichuk, O.A., Androsova, F.S., Elivanova, A.M. (2013). Khudozhestvennyi diskurs: sintaksis, ekspressivnost', strategii [Artistic Discourse: Syntax, Expressiveness, Strategies]. Yakutsk, North-Eastern Federal University Publishers, 194 p.

Ziuzina, I.A., Suvorova, P.E. (2016). Avtorskie strategii v pragmatike khudozhestvennogo diskursa na materiale trilogii «Vlastelin Kolets» Dzh-R-RTolkiena [Author's Strategies in Pragmatics of the Art Discourse on the Material of the Trilogy "Lord of the Rings" by J.R.R. Tolkien]. In Vestnik Volzhskogo universiteta im. V.N. Tatishcheva [Vestnik of Volzhsky University named after V.N. Tatischev], 1, $43-50$.

\title{
Стратегия субъективизации авторского высказывания в англоязычном литературном ксенонарративе
}

\author{
Л. В. Куликова, Е. Ю. Микалаускайте \\ Сибирский федеральныий университет \\ Россия, 660041, Красноярск, пр. Свободный, 79
}

Литературный ксенонарратив представляет собой текст, иллюстрирующий опьт взаимодействия с культурной чужеродностью, фокусируя внимание на противопоставлении категорий «свой/чужой». Функциями ксенонарратива являются минимизация стресса адаптации и трансфер ментального опыта. Автор ксенонарратива формирует представление об идеальном читателе через реализачию стратегий, направленных на рещипиента. Стратегия субъективизации авторского высказывания в литературной коммуникации направлена на личностное принятие читателем авторских смыслов в тексте, эмоциональную вовлеченность и эмпатию читателя. 
Этот процесс репрезентируется через лексические и эмоичонально-коннотативнье языковые средства в ксенонарративных текстах, а также в корпусе читательских рецензий. Результаты исследования свидетельствуют о разнице процесса субъективизачии, понимания содержательных и эмочиональных интенций автора у читателей с разными начиональными картинами мира. Англоязычные читатели зафиксировали характерные для ксенонарратива тематические блоки, проявили высокий уровень эмпатии к опыту иммигрантов, связанный с личным опытом преодоления чужеродности. Русскоязычные читатели в меньшей степени актуализировали тематический блок, связанный с межкультурным взаимодействием, они сфокусировали внимание на истории взросления.

Ключевые слова: нарратология, ксенонарратив, стратегия субъективизации литературного нарратива, межкультурная коммуникация.

Исследование проведено на материале электронного корпуса англоязычных и русскоязычных читательских отзывов/рецензий на анализируемый нарративный текст.

Научная специальность: 10.02.00 - языкознание. 